\title{
Volunteering for land care - A typology of civil society organizations in Austria, Germany and Switzerland as the basis for establishing new initiatives
}

\author{
Marianne Penker, Pamela Mühlmann \& Andreas Muhar
}

Keywords: traditional landscapes, cultural landscapes, land care, biocultural diversity, civil society organizations, volunteering, Austria, Germany, Switzerland

\section{Abstract}

Traditional agricultural landscapes are hotspots of biocultural diversity but often threatened by land abandonment or changes in cultivation methods. This is a particular challenge for protected areas and their mission to safeguard the local biocultural heritage. The aim of this article is to present a typology of civil society organizations that coordinate the voluntary engagement of non-farmers for collective land care and to provide insights for those who want to initiate similar volunteers' activities to preserve cultural landscapes. We analyse 20 volunteer organizations in Austria, Germany and Switzerland with regard to the formal structure, the goals pursued, the integration of volunteers and the spatial scope of the activities. In an empirically grounded, inductively deduced typification, we identify six types of volunteer organizations: (1) volunteer tourism facilitated by agencies, (2) national nature conservation associations, (3) cultural heritage volunteering, (4) regional land care associations, (5) local landscape protection initiatives, and (6) corporate volunteering. This heterogeneity has to be taken into account when discussing options for initiating new voluntary land care action as not all types can meet the practical and formal requirements in different geographical and organizational contexts.

\section{Introduction}

Traditional agricultural systems, created, shaped and maintained by generations of farmers, have resulted in outstanding landscapes, valuable biodiversity and cultural heritage (Müller 2012). Today many of these traditional landscapes are endangered as a result of land abandonment and changes in cultivation practices (Vos \& Meekes 1999). In protected areas, such as NATURA 2000 sites, national parks, biosphere reserves or UNESCO heritage sites, loss of traditional landscape elements and of the associated biocultural heritage is a particular challenge. While the value of traditional landscapes for biodiversity, heritage and tourism is internationally acknowledged, e.g. by the Alpine Convention, the European Landscape Convention or the UN initiative for the conservation and adaptive management of Globally Important Agricultural Heritage Systems, there is no clear answer to the question of who is responsible for taking care of these landscapes. Beside state-based instruments, such as legal regulations, zoning or agro-environmental schemes, many market-based mechanisms have been proposed and established (e.g. entrance fees, eat the view marketing initiatives, and all kinds of green and landscape based labels, cf. Boesch et al. 2008). Finally, many citizens feel responsible for the landscape they are living in and therefore engage in voluntary action. There is a fast growing body of literature on state(e. g. Lange 2011) and market-based mechanisms (e.g. Wilson and Hart 2000); collective voluntary action for landscape care, however, has been scarcely analysed so far. We define voluntary land care as activities to directly conserve or improve landscape qualities with no or only minimal monetary compensation for the participants.
Previous studies have analysed particular civil society organizations acting at local, national or even international level (Kieninger et al. 2011; Stenseke 2009) or the benefits and motivations of conservation volunteers (Miles et al. 1998; Bruyere \& Rappe 2007; Bell et al. 2008; Measham \& Barnett 2008). A systematic overview and analysis of different civil society organizations volunteering for land care is not yet available (in this paper we use the term organization as synonym both for formally established civil society organizations and for rather informally structured citizen's initiatives). Hence, this paper focuses on the following questions:

- Which types of citizens' initiatives active in land care can be distinguished?

- Which objectives guide their collective voluntary action?

- How are they organized?

- How do they contribute to land care?

The general aim was to derive a typology of civil society organizations active in land care from a comparative analysis in Austria, Germany and Switzerland. The spatial scope has been defined by the similar cultural and geographic contexts of these countries to allow for comparability. Most of these activities are conducted in protected mountain areas.

\section{Volunteering as a form of landscape gov- ernance}

Traditional landscapes, formerly unintended byproducts of human land use, are now regarded as a key environmental and recreational asset and are highly valued (Van Huylenbroeck et al. 1999; Laschewski \& Penker 2009). As a consequence of this valoriza- 
tion process, new regulatory structures have emerged to steer landscape development (Penker 2009). Williamson (1979) used the term governance to contrast market and state hierarchies as possible mechanisms for regulating and coordinating individuals' action. To Williamson's pair of coordination mechanisms, Powell (1990) added a third: networks (also referred to as civil society or the third sector). Landscape governance encompasses all relevant mechanisms for coordinating individual and collective landscape action (Penker 2008, 2009):

- hierarchy: top-down state regulations that involve, for example, zoning regulations of protected areas or conservation laws regulating landscape use;

- markets: horizontal market-based mechanisms of coordination, such as entrance fees to protected areas, eat-the-view or green labels encouraging consumers to pay more for goods and services that are produced with consideration for sustainable landscape development; this mechanism also includes voluntary incentive programmes, such as agro-environmental payment schemes compensating landholders for extra efforts or for renouncing on revenues due to land care services provided on their land;

- civil society and networks: third sector or civil society movements, volunteers' organizations, grassroots, community organizations, cooperations, etc.

In the first case, it would be the state's responsibility to regulate land-use practices (e.g. by forbidding the removal of hedges or by designating conservation zones with land-use restrictions). In the second case, landscape governance is the result of a business transaction: land users would provide land care services either in exchange for a price premium paid by consumers for food products or tourism services with green labels or in exchange for compensation payments such as agro-environmental payments. In the last case, land care is provided by local volunteers or civil society organizations without any financial incentive or compensation and without any top-down pressure. This article focusses on civil society organizations belonging to the last case.

\section{Analytical framework}

While there is a growing literature on the governance of voluntary and non-profit organizations (Spear et al. 2009), there is little research and no consent on how to distinguish different types of voluntary organizations. Third sector organizations - i. e. civil society groups as opposed to business and state organizations can include a diverse range of types and legal forms (Spear et al. 2009: 248). In the literature we find several typologies, drawn up on different distinguishing characteristics.

The typology of international voluntary services by Sherraden et al. (2006) addresses duration (short-term vs. medium to long-term), nature of service (services for international understanding vs. services for development aid and humanitarian relief) and degree of internationality (unilateral to transnational). Coghlan (2007) proposes a typology of tourism volunteers based on criteria derived from a sorting experiment with students: conservation vs. community work, holiday vs. research projects, environment or species studies, destinations available, role of organization, length of the trip, size or scale of the organization or location of the organization. Danielsen et al. (2008) suggest a typology of natural resource monitoring volunteers defined by their degree of local participation, ranging from no local involvement with monitoring undertaken by professionals to an entirely local effort. Looking also at volunteers and their organizations in the recording and monitoring of biodiversity, Bell et al. (2008) distinguish four ideal types: participatory environmental tourism, virtual network organizations, national non-governmental organizations, local associations.

The above mentioned literature research produced various typologies tailored to different voluntary activities, but none to land care. As we had no indications that one or the other typology could directly be transferred to volunteers in land care, we focused on four dimensions that we derived inductively from the case study documentation, bearing in mind the literature review on conservation volunteers (see above). These four dimensions are presented in the first column of Table 1. Regarding the first dimension, Kieser \& Walgenbach (2007) define organizations as social entities which have a formal structure. This enables the organization to direct the members' activities towards its goal (dimension II). As our study focuses on organizations that work with the manpower of volunteers, integration of and collaboration with these volunteers are of special importance for the analysis (dimension III). Finally, a fourth dimension addresses the spatial scope of the initiatives, which combines the scale of operation (e.g., from local to international) and the degree of specialization (e.g., on particular types of landscapes).

\section{Methods}

In the first step of the study a list of suitable initiatives in Austria, Germany and Switzerland was compiled. In addition to an internet search, an email enquiry was sent to relevant governmental authorities and non-governmental organizations at provincial and federal level, e.g., departments of environmental protection or local / regional development, organizations coordinating regional EU-funding programmes, or persons responsible for the implementation of the Local Agenda 21. The contacted offices specified relevant initiatives or referred to other appropriate authorities (snowball method, which is particularly useful for sampling interview partners of rare popula- 
Table 1 - Characterization of the studied organizations in terms of the dimensions selected for analysis $(x=$ relevant; $\mathbf{x}=$ bighly relevant; grey shades illustrate specifications of organizations included into the typology) (based on Müblmann 2009).

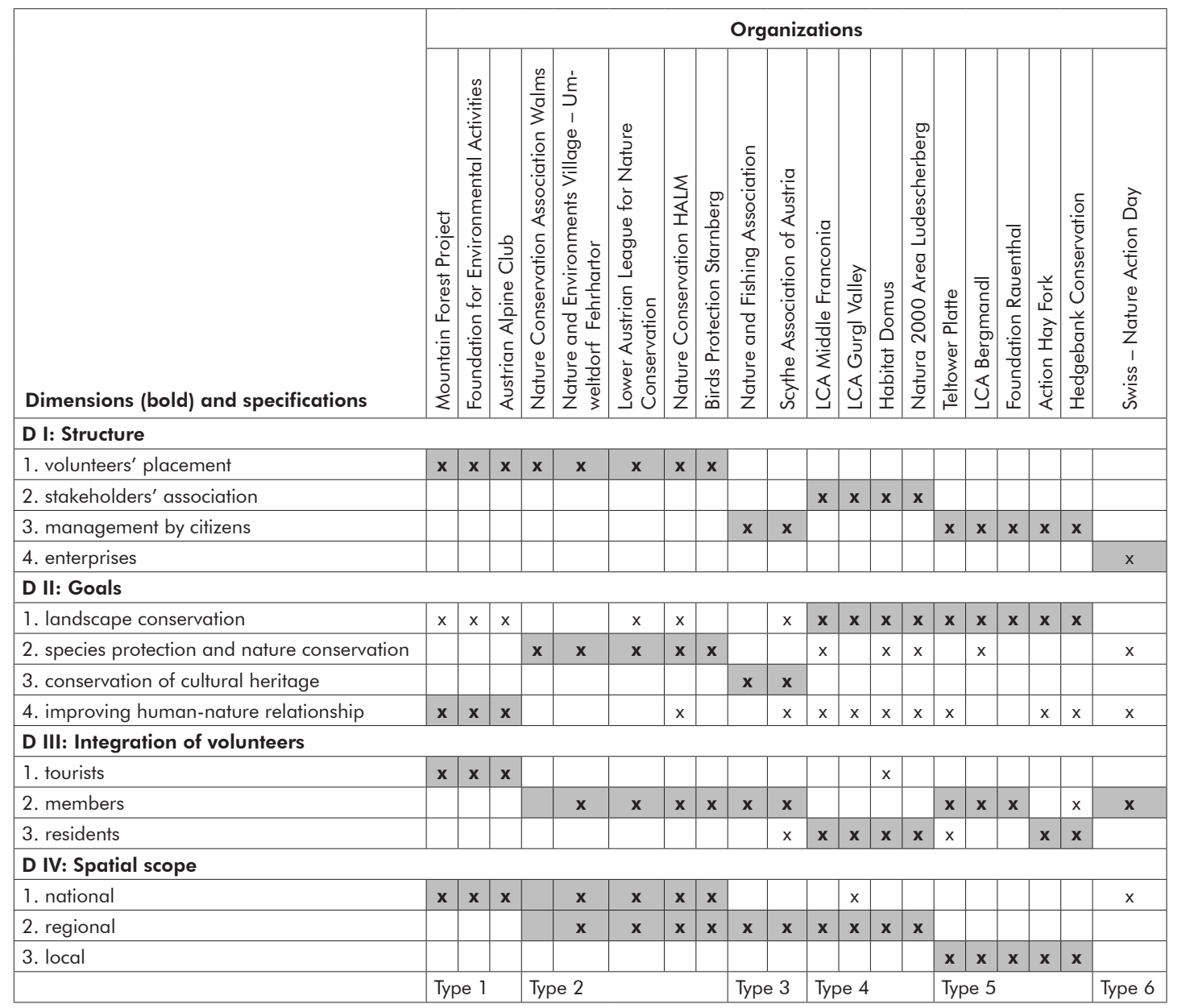

tions; Schnell et al. 2005). The inventory was closed at 35 initiatives when the same organizations had been repeatedly mentioned. From this list, 20 initiatives with a clearly documented focus on land care through the manpower of volunteers were selected for a more detailed study. The remaining 15 organizations had to be excluded, either because they were engaged in some kind of green volunteering other than land care or because they did not include physical activity (e. g. collecting money for farmers offering landscape stewardship services instead of volunteers directly providing land care activities themselves).

We asked the key actors of the initiatives, who often happened to be the initiators, for semi-structured telephone interviews. The 17 interviews took between 50 and 90 minutes; they were digitally recorded; additional handwritten notes were taken. Some interview partners provided further information material after the interview. In three cases, personal interviews could not be conducted, but there was sufficient written and online material (reports, homepage etc.) provided to perform the analysis.

Due to the restricted number of cases, a qualitative approach was applied for the inductive development of the typology. This empirically grounded develop- ment of types (Kluge 2000) involved two steps. First, different specifications for each of the four dimensions were derived by coding from the transcribed interview material (e.g. tourists, members and residents are three different specifications of integrating volunteers, dimension III). In a second step, these specifications were combined into six types.

\section{Results}

The 20 organizations were assigned to the different specifications. When several specifications were applicable, a qualitative weighting was made on the basis of the interview statements. In most cases several different objectives were mentioned but a main objective could be identified. Table 1 shows the results of the empirically grounded typification process. In the following section the six types are briefly described.

\section{Type 1 - Volunteer tourism facilitated by} agencies

This type includes organizations active at national and international level that place volunteers in land care projects. These work assignments are not restricted to a certain region or municipality. However, in or- 
der to reveal long-term effects, activities are often conducted at the same place over several years. Volunteers come to the site as working tourists. The main goal of this type of organization is to sensitize participants for nature and the preservation of the landscape through voluntary land care activities.

These organizations are formally structured as an association or foundation. Professional employees organize the land care services. Funds come from donations or fundraising campaigns and may include membership fees (in case of associations) and returns from the foundation capital. In some cases volunteers pay participation fees. All analysed organizations of this type reported more requests from volunteers than available placements.

One example for this type is the Mountain Forest Project (Bergwaldprojekt) in Switzerland, founded in 1987. It organizes one-week working holidays in mountain forest areas for people over the age of 18 in Switzerland, Germany, Austria and Ukraine. Various teams of volunteers pursue different tasks supervised and supported by skilled professionals.

Type 2 - National nature conservation associations supported by volunteers

This type involves traditional nature conservation organizations with their mission of preserving endangered plant and animal species. Voluntary land care activities are just one of many activities they organize. Land care is understood as a means to contributing to conservation and species protection and as an opportunity for awareness raising. These organizations operate on different spatial scales and in different regional subgroups. On the local and regional level the organization is sustained by citizens' commitment. Full-time employees are mostly responsible for the organization at national level.

The Austrian League for Nature Conservation (Naturschutzbund Österreich) - founded in 1913 has such a federalist structure; it is present across Austria and has twinning organizations in several other European countries. The main goal of the organization is to conserve and protect nature and - in a political sense - also to act as an advocate for nature. An example for a local representation of the Austrian League for Nature Conservation in the province of Salzburg is the HALM initiative (Heimisches Artenund Lebensraum-Management) for local species and habitat management.

\section{Type 3 - Cultural heritage volunteers}

The focus of this type of organization is not primarily on nature or landscape conservation but rather on the preservation of cultural heritage directly related to the landscape. One organization representing this type is the Scythe Association of Austria (Sensenverein Österreich). It aims to promote the traditional craft of mowing hay by scythe. At the same time it contributes to the conservation of the cultural land- scape. The Scythe Association is particularly active in the preservation of hay meadows, a highly endangered element of the Alpine cultural landscape. Further examples for such citizens' initiatives are volunteers preserving dry stone walls, pollarded willows or traditional orchards.

\section{Type 4 - Regional land care associations} supported by volunteers

In this type, different groups of stakeholders collaborate to preserve the landscape of a particular region, often in the context of protected area management. Land care associations (LCAs) can be found all over Germany, similar organizations have also been established in Austria and Switzerland. LCAs are organized as associations of collaborating farmers, conservationists, local politicians and other stakeholders like local residents. These stakeholders bundle their resources, knowledge and forces for an effective preservation of the regional nature and landscape. Experts in the field of landscape planning or nature conservation provide professional support, e.g., regarding management structures or the professional assessment of regional landscape conditions.

Not all LCAs work with volunteers on a regular basis. If so, the activities are organized in collaboration with local municipalities or other regional partners, to mobilize as many residents as possible. The voluntary land care activities are generally conducted in the same place over several years to produce sustainable improvement and to demonstrate long-term changes to the volunteers.

One example is the Land Care Association of Middle Franconia (Landschaftspflegeverband Mittelfranken). It is an association subsidized by the federal state of Bavaria which supports landowners in finding sustainable solutions for certain land-use challenges. They support farmers in the transition phase to a more sustainable agriculture or villages in their land-use planning activities. One initiative is to organize so-called land care days, where local residents work as volunteers doing landscape maintenance work.

\section{Type 5 - Local landscape protection initiatives}

The main goal of this type of organization is to preserve local landscape quality by voluntary activities. These initiatives are either formally organized as associations or foundations but often also as loose networks. All work is typically conducted by volunteers without professional paid management. Costs for equipment, tools and services for volunteers during the work assignments are met from membership fees, donations or returns from the foundation capital. All organizations of this type have been founded and led by an individual person with a very high level of commitment and enthusiasm, motivated by the perception of a negative interference into their immediate living environment. 
The Hay Fork Action Group (Aktion Heugabel) in the municipality of Frastanz, Vorarlberg, Austria is a cooperation between non-agricultural local residents and farmers to preserve typical Alpine hay meadows. The members of the Hay Fork Action Group are concerned about the future of their local agriculture as the foundation of the cultural landscape and want to support both. Their activities represent a significant aspect of the local municipality's social life.

\section{Type 6 - Corporate volunteering}

As an alternative to a works outing, employees of an enterprise work for a day as land care volunteers. Landscape is maintained, volunteers experience special activities outside their usual work and the company can use this voluntary commitment for public relations.

The corporate responsibility department of the telecom company Swisscom organizes Nature Action Days when employees provide land care services in cooperation with the World Wide Fund For Nature (WWF). Volunteers receive information on the area's characteristics and the significance of their work. The assignments include an adventure aspect for participants. Social competences are trained within the group, understanding for nature and landscape and humans' relation to them are strengthened.

\section{Discussion}

Civil-society organizations in relation to governance mechanisms of the market and the state

For the discussion, we start by recalling the concept of landscape governance, distinguishing state, market and civil society mechanisms for land care (see second section of this paper).

All types described in this article clearly belong to the civil society sphere. A classification of the types identified according to the three coordination mechanisms of landscape governance, however, results in a gradient from the core of civil society to overlapping areas with state and market spheres (see Figure 1). In corporate volunteering (T6), for example, market and civil society are closely connected. Corporate activities for nature are not necessarily purely philanthropic but increasingly include advantages for the business (e.g. a better image, or new customers through cooperation with a well-known conservation organization) (Overbeek and Harms 2011). Some market orientation can also be identified for volunteer tourism (T1). Volunteers often pay for the service provided by the placement organization and thus make a business transaction with the civil society organization. Overlaps with the state sphere are particularly evident with regional land care associations (T4). In this type, government representatives and citizens collaborate, sometimes also with business representatives. Nature conservation associations (T2) are halfway into the state sphere.

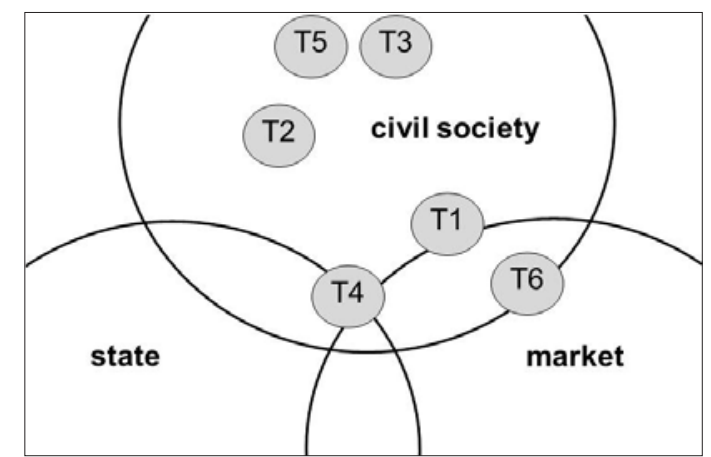

Figure 1 - Classification of the six types according to the three mechanisms of landscape governance (based on Müblmann 2009).

In their self-image they can clearly be assigned to the civil society sphere, but they often take up a mediator position vis-à-vis the state sphere. Local landscape protection initiatives (T5) and the cultural heritage volunteers (T3) have a stronger civil society character than other initiatives.

There are different theories underlying the emergence of civil society organizations (Sama 2011). The public goods or the performance failure theory suggest that civil society organizations emerge to satisfy the demand for public goods (such as scenery that individuals cannot be effectively excluded from and where use by one individual does not reduce availability to others, see for example Penker 2008) that is not covered by market or state mechanisms. Young (1999) describes different self-images of civil society organizations as supplemental, completive or antagonistic. The local landscape protection initiatives (T5), the cultural heritage volunteers (T3) and the nature conservation associations (T2) might perceive themselves as substitute for market and state mechanism and, to a lesser degree, as partners. In contrast, land care associations (T4) share experiences, resources and expertise between state, market and civil society representatives, and thus complement each of them. Under such arrangements, the theory of partnership could be argued for the emergence of civil society organizations as partners (Salamon \& Anheier 1998). None of the interviewed partners explicitly referred to their civil society organization as opponents or competitors of the market or the state.

\section{Limitations of the study}

As this is an explorative study in the restricted context of three Central European countries, we cannot give any indication regarding the generalizability and transferability of our typology. In contrast, comparative studies in other geographical contexts would be very insightful and could add further types of organizations active in land care. Looking back, we consider our methodological and analytic approach as adequate and helpful for identifying different types of civil society organizations. When interpreting the results, the following limitations, however, have to be taken into 
Table 2 - Suitability of the identified types of voluntary landscape care under different framework conditions.

\begin{tabular}{|l|c|c|c|c|c|c|}
\hline \multirow{2}{*}{ Type } & \multicolumn{5}{|c|}{ Criteria } \\
\cline { 2 - 7 } & Landscape characteristics & Expertise needed & \multicolumn{2}{c|}{ Required formal status } \\
\cline { 2 - 7 } & out-standing & ordinary & specialised & simple & ability to contract & informal \\
\hline Volunteer tourism facilitated by agencies & $\mathrm{x}$ & & & $\mathrm{x}$ & $\mathrm{x}$ & \\
\hline $\begin{array}{l}\text { National nature conservation associations } \\
\text { supported by volunteers }\end{array}$ & $\mathrm{x}$ & $\mathrm{x}$ & $\mathrm{x}$ & $\mathrm{x}$ & $\mathrm{x}$ & $\mathrm{x}$ \\
\hline Cultural heritage volunteers & $\mathrm{x}$ & $\mathrm{x}$ & $\mathrm{x}$ & & $\mathrm{x}$ & $\mathrm{x}$ \\
\hline $\begin{array}{l}\text { Regional land care associations supported } \\
\text { by volunteers }\end{array}$ & $\mathrm{x}$ & $\mathrm{x}$ & & $\mathrm{x}$ & $\mathrm{x}$ & $\mathrm{x}$ \\
\hline Local landscape protection initiatives & $\mathrm{x}$ & $\mathrm{x}$ & $\mathrm{x}$ & $\mathrm{x}$ & & $\mathrm{x}$ \\
\hline Corporate volunteering & $\mathrm{x}$ & & & $\mathrm{x}$ & $\mathrm{x}$ & \\
\hline
\end{tabular}

account: our analytic framework focuses on collective goals; individual motivations (such as social interaction, individual experience of nature or manual work) are not included. And, of course, by focusing on civil society organizations, our typology does exclude totally informal (and therefore often invisible) neighbourhood initiatives and the activities of individuals, neither of which has as yet received enough attention in research.

\section{Conclusions and management implications}

Traditional landscapes in the Alps and elsewhere are valued for their biodiversity, cultural heritage and aesthetic qualities. In the context of unwanted landscape change, volunteers take on responsibility for land care. They invest time, manual labour and money to support the conservation of the traditional landscape. The focus of voluntary work is on measures to preserve a certain state of landscapes, e. g. by removing weeds, scrubs and trees as the unwanted effects of the abandonment of agricultural cultivation.

The organizations described in this paper are very heterogeneous in size, formal structure, objectives, the spatial scope of action and in the ways in which they involve volunteers in land care. Management tasks may be carried out by full-time - i.e. paid - staff or through unpaid civil society volunteers.

For the initiation of voluntary land care action, three main aspects need to be considered to make an informed distinction between the different types of organizations: the landscape characteristics, the expertise needed and the required formal status (see Table 2). Table 2 and the considerations below provide decision support for protected area managers, public authorities or regional managers who want to initiate voluntary action, but also for local grassroots looking for a more formal mode of organization.

\section{Landscape characteristics}

This aspect can be pinned down to the following question: Is the landscape only of local value or is it also valued at national or even international level for its outstanding ecological, aesthetical or culturalhistorical characteristics? Local residents will feel attached to ordinary landscapes as places of their child- hood and their everyday life. They can be addressed via local communication channels and are motivated by the involvement in the local community as well as by reference to cultural traditions. Our research shows that corporate or tourism volunteers are instead attracted by outstanding landscapes, often far away from their place of work or living. The higher the popularity of these landscapes (e.g. UNESCO World Heritage Sites, national parks), the easier it is for both corporations and volunteer tourism organizations to promote their activities to a wide audience on websites or in brochures.

\section{Expertise needed}

The second question is: Which skills and experience should the volunteers contribute? Volunteers in local subgroups of nature conservation associations or local land care initiatives can build up impressive levels of skills and site-specific knowledge over the years (e.g., for managing sensitive ecosystems or for operating machines with high risk of injury for unskilled participants). Other types of organizations (regional land care associations, corporate volunteers or volunteer tourists) have to rely on ever-changing groups of volunteers who often can only contribute simple manual work after a brief on-site instruction (e.g. in removing neophytes). When it comes to scything, restoring and building dry stone walls or traditional fences, traditional skills can even become the primary motivator for the volunteers (e.g. for cultural heritage volunteers). In all cases, the expected level of expertise and the individual assignment of tasks have to be reflected also with regard to safety issues and options for insurance cover which usually cannot be provided by rather informally structured initiatives (see below).

\section{Formal status of the organization}

This third aspect becomes relevant when land care volunteering is to be established in the context of formalized processes, such as management schemes for protected areas or regional development programmes. Some local landscape protection initiatives are not even formally registered as associations and therefore cannot act as contract partners in the legal sense, which makes it very difficult to incorporate them into comprehensive collaborative actions such as those un- 
der the EU-funded Alpine Space programme. Even the simple provision of machinery needed for individual work tasks might require some legally valid signature under a lease contract. In practice this often results in a significant accumulation of liability risks with individual group leaders, who then act as official contract partners.

The reasons for initiating volunteer organizations analysed in this article show a specific pattern. Particularly local initiatives were generally motivated by the experience of unwelcome local landscape developments. This is an indication for a supplementary role of civil society, filling gaps opened by market and / or state failure. It was not within the scope of our paper to discuss whether this landscape governance approach is favourable to other approaches, such as changing agro-environmental payment schemes or promoting the re-wildering of landscapes. Very likely the question to pose in future research is not necessarily whether the market, the state or civil society is most responsible, appropriate or competent for landscape governance. More pressing is probably the question of how to cooperate for an effective management of diverse landscapes.

\section{Acknowledgements}

This paper has been prepared within the framework of the Doctoral School Sustainable Development (DOKNE) at BOKU University of Natural Resources and Life Sciences, Vienna (see Muhar et al. 2013), funded by the Austrian Sustainability Research Program proVISION of the Federal Ministry of Science and Research, by the Federal Ministry of Agriculture, Forestry, Environment and Water Management (BMLFUW) and by the Provinces of Lower Austria, Styria, and Vienna. We would like to thank all scientific and transdisciplinary local partners for their commitment and collaboration in the research project. We are also very grateful for Christina Roder's assistance with the English language editing.

\section{References}

Bell, S., M. Marzano, J. Cent, H. Kobierska, D. Podjed, D. Vandinzskaite, H. Reinert, A. Armaitiene, M. Grodińska-Jurczak \& R. Muršič 2008. What counts? Volunteers and their organisations in the recording and monitoring of biodiversity. Biodiversity and Conservation 17 (14): 3443-3454.

Boesch, M., E. Renner \& D. Siegrist 2008. "Brandscaping": From traditional cultural landscapes to "Label regions": A strategic scheme to achieve sustainable regional development in the Swiss Alps. Mountain Research and Development 28 (2): 100-104.

Bruyere, B. \& S. Rappe 2007. Identifying the motivations of environmental volunteers. Journal of Environmental Planning and Management 50 (4): 503-516.
Coghlan, A. 2007. Towards an integrated imagebased typology of volunteer tourism organisations. Journal of Sustainable Tourism 15 (3): 267-287.

Danielsen, F., N.D. Burgess, A. Balmford, P.F. Donald, M. Funder, J.P.G. Jones, P. Alviola, D.S. Balete, T. Blomley, J. Brashares, B. Child, M. Enghoff, J. Fjelds, S. Holt, H. Hübertz, A.E. Jensen, P.M. Jensen, J. Massao, M.M. Mendoza, Y. Ngaga, M.K. Poulsen, R. Rueda, M. Sam, T. Skielboe, G. Stuart-Hill, E. ToppJørgensen \& D. Yonten 2008. Local participation in natural resource monitoring: A characterization of approaches. Conservation Biology 23 (1): 31-42.

Kieninger, P., M. Penker \& E. Yamaji 2011. Urban people as paddy farmers - The Japanese Tanada Ownership System discussed from a European perspective. Renewable Agriculture and Food Systems 26 (4): 328-341.

Kieser, A. \& P. Walgenbach 2007. Organisation. Stuttgart.

Kluge, S. 2000. Empirically grounded construction of types and typologies in qualitative social research. Forum: Qualitative Social Research 1 (1): Art.14. Available at: http://www.qualitative-research.net/ index.php/fqs/article/view/1124/2499 (accessed: 13/03/2013).

Lange, S. 2011. Biosphere reserves in the mountains of the world and their standing after 40 years of UNESCO's MAB Programme. eco.mont 3 (1): 55-58.

Laschewski, L. \& M. Penker 2009. Rural change and the revalorisation of rural property objects. Editorial of the special issue on 'Rural Change: Revalorization of property objects and the institutionalization of (new) property rights'. International Journal of $A g$ ricultural Resources, Governance and Ecology (IJARGE) 8 (1): 1-13.

Measham, T.G. \& G. Barnett 2008. Environmental volunteering: Motivations, modes and outcomes. Australian Geographer 39 (4): 537-552.

Miles, I., W.C. Sullivan \& F.E. Kuo 1998. Ecological restoration volunteers: The benefits of participation. Urban Ecosystems 2 (1): 27-41.

Muhar, A., J.Visser \& J. van Breda 2013. Experiences from establishing structured inter- and transdisciplinary doctoral programs in sustainability: a comparison of two cases in South Africa and Austria. Journal of Cleaner Production 61: 122-129

Mühlmann, P. 2009. Zivilgesellschaftliches Engagement in der Landschaft. Das Modell freiwilliger Arbeit in der Landschaftspflege. Doctoral thesis, University of Natural Resources and Life Sciences, Vienna, Austria.

Müller, M. 2012. Surveying cultural landscape elements across the Alpine Space. eco.mont 4 (1): 47-52.

Overbeek, G. \& B. Harms 2011: From sponsor to partner: NGO-business alliances that support nature conservation in the Netherlands. Journal of Integrative Environmental Sciences 2011: 1-14. First article. DOI:10. 1080/1943815X.2011.608071.

Penker, M. 2008. Governing Austrian Landscapes: Shifts Along the Private-Public Divide. In: Sikor, T. 
(ed.), Public and Private in Natural Resource Governance. A False Dichotomy? London: 89-106.

Penker, M. 2009. Landscape governance for or by the local population? A property rights analysis in Austria. Land Use Policy 26 (49): 947-953.

Powell, W.W. 1990. Neither market nor hierarchy: Network forms of organization. Research in Organizational Behavior 12: 295-336.

Salamon, L.M. \& H.K. Anheier 1998. Social origins of civil society: Explaining the nonprofit sector crossnationally. Voluntas: International Journal of Voluntary and Nonprofit Organizations 9 (3): 213-248.

Sama, T.B. 2011. Conceptualizing Non-Governmental Organizations: Still Searching For a Theory. (Paper presented at EGPA 2009 Conference, Permanent Study Group on Third Sector, "The Public Service: Service Delivery in the Information Age", Malta. Available at: http://www.thefreelibrary.com/ Conceptualizing+ non-governmentals $\% 3 \mathrm{~A}+$ still+sear ching+for+conceptual...-a0229543175

Schnell, R., P.B. Hill \& E. Esser 2005. Methoden der empirischen Sozialforschung. München und Wien.

Sherraden, M.S., J. Stringham, S.C. Sow \& A.M. McBride 2006. The forms and structure of international voluntary service. Voluntas 17: 163-180.

Spear, R., C. Cornforth \& M. Aiken 2009. The governance challenges of social enterprises: Evidence from a UK empirical study. Annals of Public and Cooperative Economics 80 (2): 247-273.

Stenseke, M. 2009. Local participation in cultural landscape maintenance: Lessons from Sweden. Land Use Policy 26 (2): 214-223.

Van Huylenbroeck, G., A. Coppens \& M. Whitby 1999. Introduction to research on countryside stewardship policies. In: Van Huylenbroeck, G. \& M. Whitby (eds.), Countryside Stewardship: Farmers, Policies and Markets. Amsterdam: 1-19.

Vos, W. \& H. Meekes 1999. Trends in European cultural landscape development: perspectives for a sustainable future. Landscape and Urban Planning 46 (13): 3-14.

Williamson, O.E. 1979. Transaction-cost economics: The governance of contractual relations. Journal of Law and Economics 22 (2): 233-261.

Wilson, G.A. \& K. Hart 2000. Financial imperative or conservation concern? EU farmers' motivations for participation in voluntary agri-environmental schemes. Environment and Planning A 32 (12): 2161-2185.

Young, D.R. 1999. Complementary, supplementary, or adversarial? A theoretical and historical examination of nonprofit - government relations in the United States. In: Boris, E.T. \& C.E. Steuerle (eds.), Nonprofit and government. Collaboration and conflict. Washington D.C.: 31-67.

\section{Authors}

\section{Marianne Penker}

Associate Professor of Regional Development at the Institute for Sustainable Economic Development, with a research focus on regional development, participation and collective action, landscape governance, and sustainable food production.

Department of Economics and Social Sciences, BOKU University of Natural Resources and Life Sciences, Vienna; Feistmantelst. 4, 1180 Vienna, Austria E-mail: penker@boku.ac.at

\section{Pamela Mühlmann}

Graduate from the Doctoral School of Sustainable Development at BOKU University of Natural Resources and Life Sciences Vienna. Expert on governance and social innovation at the European Secretariat of ICLEI Local Governments for Sustainable Development. ICLEI European Secretariat; Leopoldring 3, 79098 Freiburg, Germany. E-mail: pamela.muehlmann@iclei.org

\section{Andreas Muhar}

Head of the Institute of Landscape Development, Recreation and Conservation Planning, and of the Doctoral School of Sustainable Development at BOKU University of Natural Resources and Life Sciences Vienna. His research focuses on sustainable landscape development, landscape-based tourism and knowledge integration. Department of Landscape, Spatial and Infrastructure Sciences; BOKU University of Natural Resources and Life Sciences Vienna; Peter Jordan-Straße 82, 1190 Vienna, Austria E-mail: andreas.muhar@boku.ac.at 